Fall 2000

\title{
The Relationship between the Functional Orientation of Senior Managers and Service Quality in LTL Motor Carriers
}

\author{
Patricia M. Poli \\ Fairfield University, ppoli@fairfield.edu \\ Carl Scheraga \\ Fairfield University, cscheraga@fairfield.edu
}

Follow this and additional works at: https://digitalcommons.fairfield.edu/business-facultypubs

Copyright 2000 Delta Nu Alpha Transportation Fraternity

Archived with permission from the copyright holder.

\section{Peer Reviewed}

\section{Repository Citation}

Poli, Patricia M. and Scheraga, Carl, "The Relationship between the Functional Orientation of Senior Managers and Service Quality in LTL Motor Carriers" (2000). Business Faculty Publications. 129.

https://digitalcommons.fairfield.edu/business-facultypubs/129

\section{Published Citation}

Poli, Patricia M., and Carl Scheraga. "The Relationship between the Functional Orientation of Senior Managers and Service Quality in LTL Motor Carriers," Journal of Transportation Management, Fall 2000, p. 17.

This item has been accepted for inclusion in DigitalCommons@Fairfield by an authorized administrator of DigitalCommons@Fairfield. It is brought to you by DigitalCommons@Fairfield with permission from the rightsholder(s) and is protected by copyright and/or related rights. You are free to use this item in any way that is permitted by the copyright and related rights legislation that applies to your use. For other uses, you need to obtain permission from the rights-holder(s) directly, unless additional rights are indicated by a Creative Commons license in the record and/or on the work itself. For more information, please contact digitalcommons@fairfield.edu. 


\title{
THE RELATIONSHIP BETWEEN THE FUNCTIONAL ORIENTATION OF SENIOR MANAGERS AND SERVICE QUALITY IN LTL MOTOR CARRIERS
}

\author{
Patricia M. Poli \\ Fairfield University \\ Carl A. Scheraga \\ Fairfield University
}

\begin{abstract}
This study utilizes data envelopment analysis to examine the relationship between the functional heterogeneity of senior LTL motor carrier managers' departmental positions and the relative efficiency of their companies in the production of quality customer service. Three measures from the Quest for Quality annual survey are utilized to measure customer satisfaction: on-time performance, value, and customer service.
\end{abstract}

It is shown that data envelopment analysis can be used to assist LTL motor carriers in benchmarking the configuration of their managerial hierarchies against their peers in order to achieve the goal of customer satisfaction. The results of the present study confirm that senior level managers in operations and marketing-oriented functions have become more prevalent in the current deregulated operating environment. Furthermore, the results suggest that an optimal balance between senior level managers in market-oriented functions and those in operations-oriented functions does exist when the targeted objective is customer satisfaction. The study also demonstrates that most LTL motor carriers were relatively inefficient in their configuration of these senior level managers.

\section{INTRODUCTION}

Since the enactment of the Motor Carrier Act of 1980, researchers have often attempted to ascertain the determinants of the freight carrier selection process. This issue has assumed greater urgency of late as reflected by the results of a joint study by the University of Tennessee, Mercer Management Consulting, and Ernst \& Young, LLP (Holcomb and Manrodt, 2000) which found that shippers in the study had made a conscious effort to reduce the number of carriers 
used. Many studies have examined the overall quality of service and its relationship to costs. Specifically, McGinnis (1990) reviewed empirical studies done during the 1970's and 1980's to address the relative importance of service and cost as determinants of the transportation choice decision and whether this choice changed after deregulation. It was found for the periods before and after deregulation that cost was a major factor only after service objectives were met. ${ }^{1}$ Taylor and Meinert (2000) state that even though low cost was important, it was not the only concern of shippers. Lambert, et al. (1993) also found that greater emphasis on the quality of service delivered was more important to shippers than low rates. D'Aveni (1995) has noted that as competition increases, the value (ratio of quality to cost) offered by firms causes customers to move toward the firm offering the higher value at a given price. Holcomb and Manrodt (2000) further found that carriers must better understand the needs of their customers in order to provide this greater value. In order to offer low prices, companies continuously search for ways to decrease operating costs without sacrificing the quality their customers expect. Liu (1993) developed an equilibrium model taking the service quality levels as given with the carriers competing by setting rates. It was found that only a small number of competing carriers could coexist in a market of intense competition where shippers demand high service quality yet want to control costs. Additionally, Allen and Liu (1995) found that excluding service quality measures from the cost estimation functions underestimates scale economies.

Wisner and Lewis (1996) examined the quality issue from the carrier's perspective in a survey of transportation company members of the American Society of Transportation and Logistics. They found that quality of service is also a concern of the carriers. The survey found that many companies have implemented formal quality improvement programs and appear to be committed to quality improvement.
Crosby (1979) defines quality as "conformance to requirements." The problem with this definition is that the

... customer often perceives the quality of the intangible service differently than the provider does. It is this difference in perception of service that creates polarization in defining and satisfying transportation customers . . (Crosby, 1979, p. 63).

Parasuraman, et al. (1985) further state that consumers use their expectations, coupled with perception of performance, to measure the quality of service delivered.

Many variables have been used to measure quality. In a review of the marketing literature, Parasuraman, et al. (1985) provide some insight into service quality determinants. They found the following determinants of service quality: reliability, responsiveness, competence, access, courtesy, communication, credibility, security, understanding of the customer and tangible measures. The tangible measures include physical facilities, equipment and per-sonnel. Lambert, et al. (1993) found that 16 of the 18 variables rated most important by their survey respondents were service related. The four variables ranked highest were quality of dispatch personnel, on-time pickups, on-time deliveries, and competitive rates. Allen and Liu (1995) used a service index and convenience index from Distribution magazine's annual “Quest for Quality Survey." Liu (1993) used transit time as a proxy for service quality. Chow and Poist (1984) used seven categories of overall service quality in their survey of transportation choice decision makers. They found that a significant number of decision makers do not record the carrier attributes which are rated as highly important in the carrier selection decision. However, the factors that were recorded, either formally or informally, related to rates, claims, transit time, equipment, and operations. 
McGinnis (1989) identified the following five service variables: reliability, transit time, specific shipper needs, over, short, or damaged freight, and specific carrier characteristics.

This study investigates the relationship between the level of customer-perceived quality and the functional orientation of senior managers in LTL companies. Early work done by Dearborn and Simon (1958) is extensively cited in the literature as providing evidence that managerial cognition is influenced by their functional experience. A group of 23 executives, all employed by the same large manufacturing firm and enrolled in a company sponsored executive training program were asked to read a standard policy case. Dearborn and Simon collected brief statements from these executives about the most important problem they perceived in the case. An analysis of these statements allowed them to relate the function from which a particular manager came and the type of problem identified. From this they concluded that executives are more focused on those items that specifically relate to their job functions.

Several criticisms can be directed at this study. The sample size was small and all the managers were attending an executive training program. Such programs tend to stress the importance of developing general management perspectives. Additionally, all participants were from the same firm. Most notably, the instructions given to the participants were interpreted inconsistently. They were asked to note the most important problem, but, in fact, Dearborn and Simon note that several listed up to three problems.

Walsh (1988) sought to extend the work of Dearborn and Simon. Utilizing the notion that managers' belief structures are derived from their experience and that past functional, organizational, and industry experiences may be influential in shaping belief structures, he sought to study the effect of a manager's belief structure on the problem identification process. In his study Walsh used 121 mid-career managers who were enrolled in a two-year, part-time executive masters degree program at a large university.
In the first part of the experiment, each manager was given a randomly ordered deck of 50 cards. Each card contained a factor broadly related to the success of an organization. Walsh used three main functional groupings in the study. These were human relations, accounting/finance and marketing. The managers were asked to sort the cards into piles of related factors and to rank the importance of these piles. In the second part of the experiment, the managers were given the three-page case history and they were asked to identify the problem or problems facing the company. This case was deliberately designed to contain an ill-structured situation with associated issues that spanned a number of functional domains.

The results of both parts of the experiment stand in interesting contrast to the Dearborn and Simon study. Walsh found that 49 percent of the managers in his sample had a "generalist" orientation. However, as with the Dearborn and Simon study, several problems have been noted. Some of the factors presented on the cards, which were purportedly related to causing organization success, could also be regarded as measures of success. Additionally, the list of factors seemed to contain many factors that could not clearly be associated with any particular function. Finally, as with the Dearborn and Simon study, the sample was drawn from an executive trainingtype program.

A study undertaken by Nystrom (1991) utilized a sample of 73 alumni of an executive MBA program. Thus, there was the inherent limitation noted above with regard to the two earlier studies. Using a framework similar to Dess and Davis (1984), Nystrom derived a list of generic competitive methods based on Porter's competitive strategies. Participants were asked to rate how important particular competitive methods were to their company's overall strategy. The results of this experiment were twofold. First, managers of production and finance departments tended to perceive competitive methods associated with a low-cost strategy as being more important than their counterparts in marketing and R\&D departments. Second, managers of 
marketing and R\&D departments tended to perceive those competitive methods associated with a product-differentiation strategy as being more important than their counterparts in production and finance departments.

Bowman and Daniels (1995) undertook a study utilizing a more representative sample of managers (not based on an association with an executive development program) and a larger sample size. Additionally, they did not use the case-based approach of the Dearborn and Simon and Walsh studies. The sample used in this study was 319 managers from 42 different strategic business units in the United Kingdom. Bowman and Daniels, utilizing the methodology employed by Nystrom, found several statistically significant results. First, production/operations managers rated cost control priorities higher than managers in finance/accounting, sales/ marketing, or general management. Second, sales/marketing managers rated differentiation priorities higher than all other managers. Third, finance/accounting and sales/marketing managers rated cost control priorities lower than the other management groups. Finally, finance/ accounting and production/operations managers rated differentiation priorities lower than other managers.

Corsi, Grimm and Feitler (1992) examine the impact of deregulation on LTL motor carriers with regard to size, structure, and organization. Of particular relevance to the present study is their hypothesis that the deregulated environment is one where managerial skills relating to marketing and product development are perceived as having greater value than those focused on accounting and production. Marketing includes issues of pricing and sales. They utilized a matched sample of 96 LTL motor carriers for 1977 and 1987. They examined the job titles of senior managers and identified eleven functional managerial categories. These categories were grouped into the three subgroups of market-oriented, regulatory-oriented, and other functions. Job titles included in the market-oriented category were marketing, rates/tariffs, and finance/comptroller while those in the regulatory-oriented category were law, claims, and traffic management. All other job titles were included in the "other" category. Their results suggest a statistically significant change in the distribution of senior managers among the three subgroups with the number of managers in market-oriented functions increasing at the expense of regulatory-oriented functions.

\section{DESIGN OF THE STUDY}

This study utilizes the annual Quest for Quality survey which is the most extensive research study conducted to evaluate and measure transportation providers in the logistics industry. It also attempts to determine the relevant criteria for customers in their selection of a particular type of carrier. Results from the last several years of surveys have strongly indicated that the three most important attributes in evaluating LTL carriers are on-time performance, value and customer service. The highest rated critical category was on-time performance, being seen as even more important than price. Furthermore, when LTL carriers arrive on schedule, shipping operations run smoothly and there are fewer backups at loading docks.

Such performance benchmarks have become particularly important for LTLs in the last few years. Comments provided by respondents to the survey over the period 1993 to 1997 suggest a trend on the part of LTL buyers to reduce the number of carriers with whom they have working relationships. This places a greater emphasis on monitoring contracts and service and switching carriers if necessary.

Clearly, the value-added activities noted above have become strategic priorities for LTL carriers. At the same time, the prioritization of the activities is a function of the perceptions of toplevel managers. In fact, it has been suggested that the composition of the functional orientation of senior managers should be actively managed (Hambrick and Mason, 1984; Abernathy, 1980). In this spirit, this study investigates the 
relationship between the functional orientation of top level managers and the ability of LTL carriers to achieve relatively superior performance with regard to the three measures of on-time performance, value and customer service.

The current study uses data envelopment analysis (DEA) to investigate the relationship between the functional heterogeneity of senior LTL motor carrier managers' departmental positions and the relative efficiency of their companies in the production of quality customer service. Drawing upon the results of the previous studies, it is argued that the functional background of senior managers will influence the motor carriers' overall choice of competitive strategies as defined by Porter. Thus, the results of the analysis will also suggest whether or not a motor carrier's choices with regard to competitive strategies are aligned with their ability to provide quality customer service. A statistical analysis is also undertaken to examine the relationship between a motor carrier's relative efficiency with regard to the production of customer service and profitability.

The next section describes the data used in the analysis. An explanation of the DEA methodology follows along with a discussion and evaluation of the results.

\section{DATA COLLECTION}

Two years of data are included in this study: 1993 and 1997. These years represent end-points of a five-year period with the most complete set of necessary data. The carriers used in this study are those with complete information regarding the functional affiliations of senior managers. This information is obtained from the Official Motor Carrier Directory for the years 1993 and 1997. The quality of customer service scores is obtained from the Quest for Quality surveys. A final sample of 32 LTL motor carriers (64 observations) for the years 1993 and 1997 is obtained that meets the above criteria.
The input data variables used in this study relate to the functional categories of senior managers and is similar to those of the Corsi, Grimm, and Feitler (1992) study: financial, maintenance or safety, marketing, and operations. The financialoriented category includes such activity titles as rates/tariffs, finance, and comptroller. The marketing-oriented group includes marketing, sales and customer relations. The maintenance/ safety category includes maintenance and safety titles. The operations-oriented category includes operations and traffic management. All other activity titles are placed in the "other" category and are not used in this study. The percentages of total senior managers for each of the four categories are the input variables. Panel A of Table 1 lists descriptive statistics for the input variables. The average percent of senior managers with a maintenance or safety title is lowest (8\%). In fact, 26 of the 64 observations (41\%) employ no senior managers with maintenance or safety titles. On average, the companies employ more senior managers with operation-oriented titles than any other title (22\%).

The outputs in this study are the customer service measures of three dimensions of quality from the Quest for Quality survey: on-time performance, value, and customer service. Carriers are rated on a three-point scale $(3=$ outstanding; 2 = average; $1=$ poor) that is then averaged and reported in the survey results. The on-time performance variable measures a carrier's performance with regard to pickup and delivery, consistent and dependable schedules and transit times, and equipment availability. The value variable measures a carrier's performance with regard to the competitiveness of rates with other carriers offering the same service, the commensurability of pricing to the service level required by the customer, and the simplicity of rates. Customer service measures a carrier's performance with regard to the prompt settlement of claims, the ability to trace and expedite shipments, and the prompt and courteous solution of problems. Minimum values for on-time performance and customer service 
TABLE 1

\section{DESCRIPTIVE STATISTICS FOR DATA VARIABLES}

PANEL A - INPUT VARIABLES ${ }^{\mathrm{a}}$

\begin{tabular}{lcccc}
\hline & Financial Titles & $\begin{array}{c}\text { Maintenance/ } \\
\text { Safety Titles }\end{array}$ & Marketing Titles & Operations Titles \\
\hline Average & $15.4 \%$ & $8.0 \%$ & $20.9 \%$ & $22.2 \%$ \\
Minimum & 0.0 & 0.0 & 0.0 & 0.0 \\
Maximum & 40.0 & 22.2 & 50.0 & 50.0 \\
Median & 14.3 & 7.4 & 20.0 & 20.0 \\
\hline
\end{tabular}

\section{PANEL B - OUTPUT VARIABLES ${ }^{b}$}

\begin{tabular}{lccc}
\hline & On-Time Performance & Value & Customer Service \\
\hline Average & 2.257 & 2.129 & 2.161 \\
Minimum & 1.880 & 1.870 & 1.790 \\
Maximum & 2.600 & 2.440 & 2.530 \\
Median & 2.260 & 2.130 & 2.155 \\
\hline
\end{tabular}

${ }^{a}$ Data are obtained from the Official Motor Carrier Directory. These data are accumulated over the two-year period of the study.

'Data are obtained from Distribution magazine's annual "Quest for Quality Survey." The ratings are based on a three-point scale ( 3 = outstanding; 2 = average; 1 = poor).

are attributable to DiSalvo-1993, while Fredrickson Motor Express-1997 received the minimum score for the value variable. American Freightways-1993 is tied with Wilson Trucking-1997 for the maximum value for on-time performance. Wilson Trucking-1997 also has the maximum values for customer service. Pitt Ohio Express1993 earns the maximum for the value variable.

\section{DATA ENVELOPMENT ANALYSIS}

The methodology employed in this study is data envelopment analysis (DEA). This methodology is used to compare the relative efficiencies of decision-making units (DMUs). The criterion for efficiency is that used in traditional microeconomic analysis with regard to production plans. A production plan is efficient if there is no way to produce more output with the same inputs or to produce the same output with fewer inputs.
DEA differs from standard econometric methodology in its implementation of the efficiency criteria noted above. The traditional parametric production function uses a specific pre-defined functional form that is assumed to apply to each DMU. DEA is a nonparametric technique that makes no assumptions about the form of the production function and instead optimizes the performance measure of each DMU. An empirical best practice production frontier is thus estimated from the actual, observed inputs and outputs of individual DMUs. This frontier replicates the behavior of individual units rather than that of the average sample estimate of parametric production functions. A DMU is therefore considered efficient when comparisons with other units indicate no inefficiency in the utilization of inputs and outputs, as measured by its position relative to the efficient production frontier. In other words, the objective of DEA is to minimize total waste in both the inputs and 
the outputs. Another important aspect of DEA is that it allows the efficiency scores to be independent of the units of measurement for the data, i.e., units-invariant.

Three sets of information are used in the analyses: input, output, and descriptive measures. Input measures represent minimizing goals, such as minimizing the number of marketing executives and/or minimizing the number of maintenance executives. Output measures represent maximizing goals such as maximizing customer service. Descriptive measures represent variables used to further discriminate between efficient and non-efficient observations.

The analysis in this study employs the input oriented model since the objective of this research is to determine whether the functional orientation of managers affects the quality of customer service. In the case of the input oriented model, one set of variables, inputs, takes priority over the output variables. This model seeks to minimize the inputs utilized. The implicit underlying premise in such an orientation is that the primary objective of the motor carrier under evaluation is to gain efficiency by reducing excess input utilization while continuing to operate with the current technology mix (reflected in actual input ratios). A measure of efficiency for the input oriented model as defined in Charnes et al. (1978) is $i$. This efficiency measure is the multiple of the input vector that would yield the current level of output. A most desirable aspect of the inputoriented model is that, because it measures inefficiency in terms of proportional changes of inputs, it allows a motor carrier to be evaluated with respect to a best practice motor carrier that is most similar to it in terms of input mix. It should be noted that an efficient observation will have an efficiency measure, $l$, of 1.000 .
The efficiency measure, $l$, conveys information with regard to managerial policy. Consider the following case. Suppose Motor Carrier A has a peer group of motor carriers that have comparatively efficient percent of senior managers with specific functional titles allowing them to achieve the levels of output of Motor Carrier A more efficiently. If $l$ is very small, then the mix of senior managers of Motor Carrier A is really off the mark and attention should be focused on shifting the input senior manager mix. If, on the other hand, $l$ is close to 1.000 , then the motor carrier could remain with its current senior manager mix and achieve the same levels of output with a small scaling down. Thus, utilization of the input oriented model allows the researcher to develop assessment measures of inefficiency and to also evaluate the efficacy of managerial strategies.

\section{RESULTS}

Table 2 presents a list of the values for the input oriented efficiency score, $l$, for each observation, with summary statistics shown in Table 3 . As shown in Panel A of Table 3, the overall values for $l$ range from 0.288 to 1.000 (efficient). The minimum value is attributable to G.I. Trucking1993. A value of 0.288 for $l$ implies that the carrier in question could have produced its current level of customer perceived quality and, at the same time, proportionally reduced all inputs in the process by 71.2 percent. Only two companies are considered efficient for both years: American Freightways, and Ward Trucking. Eighteen companies show an increase in efficiency from 1993 to 1997 with ten of those companies improving their input mix over the period to attain an efficiency measure of 1.000 in 1997. Twelve companies show a decrease in efficiency with eight companies actually starting in 1993 with an efficiency measure of 1.000 and then suffering a decrease in relative efficiency. 


\section{TABLE 2}

EFFICIENCY SCORES ${ }^{a}$

\begin{tabular}{|c|c|c|c|c|c|}
\hline $\begin{array}{c}\text { Carrier } \\
\end{array}$ & Year & $i$ & Carrier & Year & $i$ \\
\hline AAA Cooper Transportation & 1993 & 1.000 & Old Dominion Freight Lines & 1993 & 0.370 \\
\hline AAA Cooper Transportation & 1997 & 0.591 & Old Dominion Freight Lines & 1997 & 0.480 \\
\hline ABF Freight Systems & 1993 & 0.510 & Overnite Transportation & 1993 & 0.688 \\
\hline ABF Freight Systems & 1997 & 0.578 & Overnite Transportation & 1997 & 0.743 \\
\hline American Freightways & 1993 & 1.000 & Pitt Ohio Express & 1993 & 1.000 \\
\hline American Freightways & 1997 & 1.000 & Pitt Ohio Express & 1997 & 0.623 \\
\hline ANR Advance & 1993 & 0.380 & Preston Trucking Co. & 1993 & 1.000 \\
\hline ANR Advance & 1997 & 0.469 & Preston Trucking Co. & 1997 & 0.598 \\
\hline A-P-A Transport & 1993 & 0.818 & Roadway Express & 1993 & 0.716 \\
\hline A-P-A Transport & 1997 & 1.000 & Roadway Express & 1997 & 0.631 \\
\hline Averitt Express & 1993 & 1.000 & Saia Motor Freight & 1993 & 1.000 \\
\hline Averitt Express & 1997 & 0.510 & Saia Motor Freight & 1997 & 0.608 \\
\hline Con-Way Central Express & 1993 & 0.934 & Southeastern Freight Lines & 1993 & 0.812 \\
\hline Con-Way Central Express & 1997 & 0.745 & Southeastern Freight Lines & 1997 & 1.000 \\
\hline Con-Way Western Express & 1993 & 0.603 & USF Bestway (TN'T Bestway) & 1993 & 0.601 \\
\hline Con-Way Western Express & 1997 & 1.000 & USF Bestway (TNT Bestway) & 1997 & 0.477 \\
\hline Di Salvo & 1993 & 0.843 & USF Holland (TNT Holland Motor & 1993 & 0.787 \\
\hline Di Salvo & 1997 & 1.000 & USF Holland (TNT Holland & 1997 & 1.000 \\
\hline Estes Express & 1993 & 0.472 & USF Red Star & 1993 & 1.000 \\
\hline Estes Express & 1997 & 0.567 & USF Red Star & 1997 & 0.549 \\
\hline Fredrickson Motor Express & 1993 & 1.000 & USF Reddaway (TNT Reddaway) & 1993 & 0.873 \\
\hline Fredrickson Motor Express & 1997 & 0.368 & USF Reddaway (TNT & 1997 & $\mathbf{1 . 0 0 0}$ \\
\hline G.I. Trucking & 1993 & 0.288 & Viking Freight System & 1993 & 0.896 \\
\hline G.I. Trucking & 1997 & 0.335 & Viking Freight System & 1997 & 1.000 \\
\hline Lynden Transport & 1993 & 0.463 & Ward Trucking & 1993 & 1.000 \\
\hline Lynden Transport & 1997 & 1.000 & Ward Trucking & 1997 & 1.000 \\
\hline Motor Cargo & 1993 & 0.570 & Watkins Motor Lines & 1993 & 1.000 \\
\hline Motor Cargo & 1997 & 0.626 & Watkins Motor Lines & 1997 & 0.947 \\
\hline NationsWay (NW Transport) & 1993 & 0.675 & Wilson Trucking & 1993 & 0.652 \\
\hline NationsWay (NW Transport) & 1997 & 0.476 & Wilson Trucking & 1997 & 1.000 \\
\hline New England Motor Freight & 1993 & 0.972 & Yellow Freight System & 1993 & 0.811 \\
\hline New England Motor Freight & 1997 & 1.000 & Yellow Freight System & 1997 & 0.832 \\
\hline
\end{tabular}

${ }^{2} l$ is the input-oriented efficiency score. A score of 1.000 means that the observation has no inefficiency. Efficient observations are shown in bold. 


\section{TABLE 3 \\ SUMMARY STATISTICS FOR $\ell$}

\section{PANEL A \\ ALL OBSERVATIONS}

\begin{tabular}{ll}
\hline & $\boldsymbol{\iota}^{\prime \mathbf{1}}$ \\
\hline Average & 0.758 \\
Minimum & 0.288 \\
Maximum & 1.000 \\
Median & 0.800 \\
\hline
\end{tabular}

\section{PANEL B \\ INEFFICIENT OBSERVATIONS ONLY}

\begin{tabular}{lc}
\hline & \multicolumn{1}{c}{$\boldsymbol{\iota}^{\text {'a }}$} \\
\hline Average & 0.631 \\
Minimum & 0.288 \\
Maximum & 0.972 \\
Median & 0.606 \\
\hline
\end{tabular}

' $l$ is the input-oriented efficiency score. A score of 1.000 means that the observation has no inefficiency.

The number of observations with an efficiency score of 1.000 is 22 , leaving the remaining 42 observations as relatively inefficient. Although 42 observations are not considered efficient, it is important to consider the range of values within this group. Panel B of Table 3 presents summary information for $\boldsymbol{l}$ for the inefficient observations only. As previously stated, G.I. Trucking-1993 has the lowest value for $l(0.288)$; New England Motor Freight-1993 attains the maximum value of 0.972. The average value for $l$ is 0.631 . An examination of the quartiles for $l$ reveals that the second quartile ranges from 0.510 to 0.603 ; the third quartile ranges from 0.608 to 0.787 ; and the fourth quartile ranges from 0.812 to 0.972 . Some of the observations in the fourth quartile may be considered somewhat efficient in terms of having managers with the appropriate functional backgrounds necessary to produce high quality customer service. These results suggest that some companies correctly perceived the optimal training background needed to provide the level of service quality demanded by their customers.

Table 4 displays the amount of inefficiency for all observations and all variables. The amount of inefficiency compares the actual value with a projected efficient value for the specific observation. A value of 0.000 for the amount of inefficiency means that the actual input value equals the optimally calculated projected value. Input inefficiencies carry a negative sign indicating the necessary reduction for efficient operation. An examination of the amount of inefficiency for the individual input variables can be used to explain the observed range of values for $t$. For all variables, the efficient observations have the projected value equal to the actual value so the following will discuss only the results for the inefficient observations.

Three of the 42 inefficient observations operate with the actual percent of managers with financial backgrounds equal to the projected percent; 5 (2) observations have the actual equal to the optimally projected percent of marketing (operations) background; and 14 observations have the actual equal to the optimally projected percent of maintenance/safety title.

Table 5 presents summary statistics for the amount of the input inefficiencies for the inefficient observations only. Throughout the period of the study, the average level of inefficiency is 0.067 for the financial title, 0.032 for maintenance/safety, 0.077 for marketing title, and 0.091 for operations. All titles achieve the minimum amount of inefficiency $(0.000)$. The highest value for the amount of inefficiency $(-0.286)$ is denoted by a negative sign and occurs in the operations title. In examining the number of times that each title has the largest amount of inefficiency, it is noted that $43 \%$ of the observations are for the operations title, $28 \%$ are for the marketing title, $19 \%$ are for the financial title, and $10 \%$ are for the maintenance/safety title. This suggests that observations with managers having marketing backgrounds are 
TABLE 4

AMOUNT OF INEFFICIENCY ${ }^{\text {a }}$

\begin{tabular}{|c|c|c|c|c|c|}
\hline Company & Year & $\begin{array}{c}\text { Financial } \\
\text { Titles }\end{array}$ & $\begin{array}{l}\text { Maintenance/ } \\
\text { Safety Titles }\end{array}$ & $\begin{array}{c}\text { Marketing } \\
\text { Titles }\end{array}$ & $\begin{array}{c}\text { Operations } \\
\text { Titles }\end{array}$ \\
\hline AAA Cooper Transportation & 1993 & 0.000 & 0.000 & 0.000 & 0.000 \\
\hline AAA Cooper Transportation & 1997 & -0.068 & 0.000 & -0.068 & -0.116 \\
\hline ABF Freight Systems & 1993 & -0.071 & -0.036 & -0.143 & $\cdot-0.107$ \\
\hline ABF Freight Systems & 1997 & -0.032 & -0.043 & -0.159 & -0.064 \\
\hline American Freightways & 1993 & 0.000 & 0.000 & 0.000 & 0.000 \\
\hline American Freightways & 1997 & 0.000 & 0.000 & 0.000 & 0.000 \\
\hline ANR Advance & 1993 & -0.171 & -0.122 & -0.171 & -0.086 \\
\hline ANR Advance & 1997 & -0.083 & 0.000 & -0.167 & -0.083 \\
\hline A-P-A Transport & 1993 & -0.017 & 0.000 & -0.033 & -0.017 \\
\hline A-P-A Transport & 1997 & 0.000 & 0.000 & 0.000 & 0.000 \\
\hline Averitt Express & 1993 & 0.000 & 0.000 & 0.000 & 0.000 \\
\hline Averitt Express & 1997 & -0.084 & 0.000 & -0.126 & -0.186 \\
\hline Con-Way Central Express & 1993 & -0.111 & 0.000 & 0.000 & 0.000 \\
\hline Con-Way Central Express & 1997 & -0.025 & -0.050 & -0.050 & -0.050 \\
\hline Con-Way Western Express & 1993 & -0.099 & -0.074 & -0.049 & -0.049 \\
\hline Con-Way Western Express & 1997 & 0.000 & 0.000 & 0.000 & 0.000 \\
\hline Di Salvo & 1993 & -0.016 & -0.016 & -0.008 & -0.040 \\
\hline Di Salvo & 1997 & 0.000 & 0.000 & 0.000 & 0.000 \\
\hline Estes Express & 1993 & -0.115 & -0.058 & -0.173 & -0.058 \\
\hline Estes Express & 1997 & -0.088 & -0.104 & -0.071 & -0.053 \\
\hline Fredrickson Motor Express & 1993 & 0.000 & 0.000 & 0.000 & 0.000 \\
\hline Fredrickson Motor Express & 1997 & -0.050 & 0.000 & 0.000 & 0.000 \\
\hline G.I. Trucking & 1993 & -0.252 & 0.000 & -0.126 & -0.163 \\
\hline G.I. Trucking & 1997 & -0.245 & 0.000 & -0.122 & -0.152 \\
\hline Lynden Transport & 1993 & -0.086 & -0.137 & -0.173 & -0.086 \\
\hline Lynden Transport & 1997 & 0.000 & 0.000 & 0.000 & 0.000 \\
\hline Motor Cargo & 1993 & -0.105 & -0.035 & -0.035 & -0.070 \\
\hline Motor Cargo & 1997 & -0.062 & -0.031 & -0.062 & -0.062 \\
\hline NationsWay (NW Transport) & 1993 & -0.036 & -0.036 & -0.071 & -0.071 \\
\hline NationsWay (NW Transport) & 1997 & -0.149 & -0.037 & -0.074 & -0.074 \\
\hline New England Motor Freight & 1993 & 0.000 & 0.000 & 0.000 & -0.040 \\
\hline New England Motor Freight & 1997 & 0.000 & 0.000 & 0.000 & 0.000 \\
\hline Old Dominion Freight Lines & 1993 & -0.172 & 0.000 & -0.103 & -0.208 \\
\hline Old Dominion Freight Lines & 1997 & -0.047 & 0.000 & -0.140 & -0.125 \\
\hline Overnite Transportation & 1993 & -0.043 & -0.034 & -0.043 & -0.119 \\
\hline Overnite Transportation & 1997 & -0.010 & 0.000 & -0.005 & -0.286 \\
\hline Pitt Ohio Express & 1993 & 0.000 & 0.000 & 0.000 & 0.000 \\
\hline Pitt Ohio Express & 1997 & -0.047 & -0.047 & -0.140 & -0.047 \\
\hline Preston Trucking Co. & 1993 & 0.000 & 0.000 & 0.000 & 0.000 \\
\hline Preston Trucking Co. & 1997 & -0.044 & -0.122 & -0.087 & -0.087 \\
\hline Roadway Express & 1993 & -0.032 & -0.016 & -0.064 & -0.112 \\
\hline Roadway Express & 1997 & -0.044 & -0.022 & -0.087 & -0.109 \\
\hline Saia Motor Freight & 1993 & 0.000 & 0.000 & 0.000 & 0.000 \\
\hline Saia Motor Freight & 1997 & -0.049 & -0.024 & -0.097 & -0.097 \\
\hline Southeastern Freight Lines & 1993 & -0.009 & -0.018 & -0.035 & -0.166 \\
\hline Southeastern Freight Lines & 1997 & 0.000 & 0.000 & 0.000 & 0.000 \\
\hline
\end{tabular}


Table 4

(continued)

\begin{tabular}{llcccc}
\hline \multicolumn{1}{c}{ Company } & Year & $\begin{array}{c}\text { Financial } \\
\text { Titles }\end{array}$ & $\begin{array}{c}\text { Maintenance/ } \\
\text { Safety Titles }\end{array}$ & $\begin{array}{c}\text { Marketing } \\
\text { Titles }\end{array}$ & $\begin{array}{c}\text { Operations } \\
\text { Titles }\end{array}$ \\
\hline USF Bestway (TNT Bestway) & 1993 & -0.065 & -0.081 & -0.065 & -0.065 \\
USF Bestway (TNT Bestway) & 1997 & -0.094 & -0.047 & -0.141 & -0.141 \\
USF Holland (TNT Holland Motor & 1993 & -0.019 & -0.043 & -0.039 & -0.104 \\
Express) & & & & & \\
USF Holland (TNT Holland Motor & $\mathbf{1 9 9 7}$ & $\mathbf{0 . 0 0 0}$ & $\mathbf{0 . 0 0 0}$ & $\mathbf{0 . 0 0 0}$ & $\mathbf{0 . 0 0 0}$ \\
Express) & $\mathbf{1 9 9 3}$ & $\mathbf{0 . 0 0 0}$ & $\mathbf{0 . 0 0 0}$ & $\mathbf{0 . 0 0 0}$ & $\mathbf{0 . 0 0 0}$ \\
USF Red Star & 1997 & -0.101 & 0.000 & -0.101 & -0.133 \\
USF Red Star & 1993 & -0.016 & -0.016 & -0.016 & -0.066 \\
USF Reddaway (TNT Reddaway) & 1997 & $\mathbf{0 . 0 0 0}$ & $\mathbf{0 . 0 0 0}$ & $\mathbf{0 . 0 0 0}$ & $\mathbf{0 . 0 0 0}$ \\
USF Reddaway (TNT Reddaway) & 1993 & 0.000 & -0.051 & -0.015 & -0.005 \\
Viking Freight System & $\mathbf{1 9 9 7}$ & $\mathbf{0 . 0 0 0}$ & $\mathbf{0 . 0 0 0}$ & $\mathbf{0 . 0 0 0}$ & $\mathbf{0 . 0 0 0}$ \\
Viking Freight System & $\mathbf{1 9 9 3}$ & $\mathbf{0 . 0 0 0}$ & $\mathbf{0 . 0 0 0}$ & $\mathbf{0 . 0 0 0}$ & $\mathbf{0 . 0 0 0}$ \\
Ward Trucking & $\mathbf{1 9 9 7}$ & $\mathbf{0 . 0 0 0}$ & $\mathbf{0 . 0 0 0}$ & $\mathbf{0 . 0 0 0}$ & $\mathbf{0 . 0 0 0}$ \\
Ward Trucking & $\mathbf{1 9 9 3}$ & $\mathbf{0 . 0 0 0}$ & $\mathbf{0 . 0 0 0}$ & $\mathbf{0 . 0 0 0}$ & $\mathbf{0 . 0 0 0}$ \\
Watkins Motor Lines & 1997 & -0.002 & -0.002 & -0.005 & -0.111 \\
Watkins Motor Lines & 1993 & -0.022 & -0.022 & -0.132 & -0.119 \\
Wilson Trucking & $\mathbf{1 9 9 7}$ & $\mathbf{0 . 0 0 0}$ & $\mathbf{0 . 0 0 0}$ & $\mathbf{0 . 0 0 0}$ & $\mathbf{0 . 0 0 0}$ \\
Wilson Trucking & 1993 & -0.017 & -0.017 & -0.034 & -0.043 \\
Yellow Freight System & 1997 & -0.023 & -0.011 & -0.011 & -0.068 \\
Yellow Freight System & & & &
\end{tabular}

"Amount of inefficiency is calculated by subtracting the actual value from the projected efficient value. Efficient observations are shown in bold. The number of inefficient observations is 42 .

\section{TABLE 5}

\section{SUMMARY STATISTICS FOR THE AMOUNT OF INEFFICIENCY FOR INEFFICIENT OBSERVATIONS ONLY}

\begin{tabular}{|c|c|c|c|c|}
\hline & Financial Titles" & $\begin{array}{c}\text { Maintenance/Safety } \\
\text { Titles }^{\mathrm{a}}\end{array}$ & $\begin{array}{c}\text { Marketing } \\
\text { Titles }^{\mathbf{a}}\end{array}$ & Operations Titles ${ }^{a}$ \\
\hline Average & -0.067 & -0.032 & -0.077 & -0.091 \\
\hline Maximum & -0.252 & -0.137 & -0.173 & -0.286 \\
\hline Minimum & 0.000 & 0.000 & 0.000 & 0.000 \\
\hline Median & -0.048 & -0.022 & -0.069 & -0.084 \\
\hline
\end{tabular}

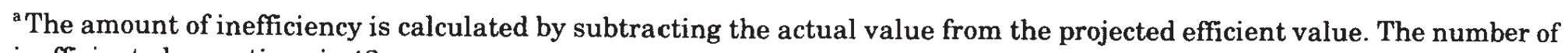
inefficient observations is 42 .

better able to strategically position their company to provide high quality customer service than those with operations titles.
Table 6 contains information regarding the Wilcoxon test performed to determine whether the efficient observations differ from the ineffi- 
TABLE 6

LINEAR RANK STATISTICS

EFFICIENT VS INEFFICIENT MOTOR CARRIERS

Panel A - Ton-Miles ${ }^{\text {a }}$

\begin{tabular}{cccc}
\hline & $\mathbf{N}^{\mathbf{b}}$ & MEAN & $\begin{array}{c}\mathbf{H}_{\mathbf{0}} \text { : Mean } \\
\text { (Inefficient) } \geq \\
\text { Mean (Efficient) }\end{array}$ \\
\hline Inefficient & 30 & $2,414,820,519$ & \\
Efficient & 15 & $736,479,973$ & \\
WILCOXON TEST & Prob $>|\mathrm{Z}|=0.043$ \\
\hline
\end{tabular}

Panel B - Operating Ratio ${ }^{\text {a }}$

\begin{tabular}{cccc}
\hline & $\mathbf{N}^{\mathbf{b}}$ & MEAN & $\begin{array}{c}\mathbf{H}_{\mathbf{0}}: \text { Mean } \\
\text { (Inefficient) } \leq \\
\text { Mean (Efficient) }\end{array}$ \\
\hline Inefficient & 35 & 0.942 & \\
$\begin{array}{c}\text { Efficient } \\
\text { WILCOXON TEST }\end{array}$ & Prob $>|\mathrm{Z}|=0.155$ \\
\hline
\end{tabular}

- Data are obtained from the American Trucking Association's financial database, Financial and Operating Statistics. These data are accumulated over the two-year period of the study.

${ }^{\text {b }}$ Complete data was not available for all observations.

cient observations in terms of size, measured by ton-miles driven, and profitability, measured by the operating ratio. It should be noted that not all observations are included in this analysis because the financial information included in the American Trucking Association's Financial and Operating Statistics database for the years 1993 and 1997 is not complete. There are no legal requirements for the carriers to file this information; so many companies do not include all requested data. The average ton-miles operated by the inefficient carriers appear to be much greater than that of the efficient carriers. However, the null hypothesis that the mean number of ton-miles operated for the inefficient observations equals or exceeds that of the efficient observations is rejected at a level of 0.043 . This suggests that efficient observations are the larger carriers. A similar test was conducted for the operating ratio. The average operating ratio for the inefficient observations is 0.942 while for the efficient observations it is 0.928 . The null hypothesis that the mean operating ratio for the inefficient observations is lower than that of the efficient observations cannot be rejected. There is no perceived difference in the profitability of the two groups.

The inefficient observations are further divided into the larger observations, defined as those with ton-miles exceeding the sample's average ton-miles. Ten observations (out of 42 inefficient observations) are in this group. $75 \%$ of those observations show the operating title as the variable with the largest amount of inefficiency, while there are none for the financial or maintenance/safety titles. The observations with an operating ratio below that of the sample's average ratio (more profitable) is fifteen out of 42. In this case, the operations title appears most often (56\% of the time) for the largest amount of inefficiency and the financial title appears least often $(2 \%)$. The maintenance/safety title appears $13 \%$ of the time and the marketing title occurs in $29 \%$ of the observations. This is consistent with the overall examination of the 42 inefficient observations and suggests that even though the larger and more profitable observations are those with inefficiency in the number of operations managers, a decrease in the number of operations managers could lead to increased customer perceived satisfaction. This also is true for the number of marketing managers.

\section{MANAGERIAL IMPLICATIONS}

The literature suggests that, even though senior managers are expected to have a generalist's view of their organization, in fact, each typically brings an orientation that has developed from experience and training in some primary functional area. Indeed, Bayster and Ford (2000) find that those in different functional classifications make significantly different decisions. The Corsi, Grimm and Feitler study (1992) suggests that the deregulated environment for LTL motor carriers is one where those managerial skills relating to marketing and product development are perceived as having 
greater value than those focused on accounting and production. This study suggests that motor carrier managerial hierarchies can do more than simply recognize this "trending" phenomenon. Specifically, the portfolio of functional expertise of senior managers should be an important aspect of the company's business strategy.

Data envelopment analysis is used to provide a quantitative framework that enables senior managers to benchmark this strategic human resource activity and to specifically identify relative inefficiencies in the existing hierarchal structure of LTL motor carriers. The manner in which the LTL configures its senior level of managers around functional categories will have a variety of strategic impacts. Managers with a marketing orientation will focus on product innovation, related diversification, advertising, and quality of customer relations. Those with an operating background will concentrate on automation, equipment newness, ability to expedite deliveries, actual performance of the service, and overall quality of the service. The maintenance/safety point of reference will stress on-time performance and lack of downtime due to equipment failures. Managers with a finance orientation will devote their attentions to competitiveness and simplicity of rate structures.

This research provides additional insight and support for previous studies regarding the organizational structure of LTL motor carriers. The results of the present study confirm that senior level managers in operations- and marketing-oriented functions are more prevalent in the current operating environment and that maintenance and safety functions are less prevalent. However, the data envelopment analysis of this study suggests that during the time period examined, most LTL motor carriers were relatively inefficient in configuring senior management hierarchies in the pursuit of their customer satisfaction objective. The results also suggest that an optimal balance between senior level managers in the four categories can be obtained to reach the targeted objective.
There are compelling reasons in the competitive environment of LTL motor carriers to actively manage this link between senior managers' proficiencies and company strategy. Many shippers are now paring down the number of carriers they use to a specific core group in order to better form win/win partnerships. Large LTL carriers must recognize the urgency to restructure their multi-tier organizational hierarchies and perhaps begin to emulate the more customer-oriented approach of the regional carriers. They will need to continue to simplify pricing structures and maintain higher levels of communication with shippers. The methodology described in this paper is an effective technique to assist LTL firms in benchmarking themselves against their peers in order to reach their strategic goals.

\section{NOTE}

M.A. McGinnis, "The Relative Importance of Cost and Service in Freight Transportation Choice: Before and After Deregulation," Transportation Journal 30.1 (1990): 112-119. For studies relating to the period prior to deregulation see: R.E. Evan and W.R. Southard, "Motor Carriers' and Shippers' Perceptions of the Carrier Choice Decisions," The Logistics and Transportation Review 10.4 (1974): 145-147; R.E. Jerman, R. D. Anderson, J. A. Constantin, "Shipper Versus Carrier Perceptions of Carrier Selection Variables, International Journal of Physical Distribution and Materials Management 9.1 (1978):29-38; M.A. McGinnis, "Shipper Attitudes Toward Freight Transportation Choice: A Factor Analytic Study, "International Journal of Physical Distribution and Materials Management 10.1 (1979):25-34; and J. R. Stock, "How Shippers Judge Carriers," Distribution Worldwide 75.8 (August 1978): 32-35.

\section{REFERENCES}

1 Consulting (1999) Integrated Data Envelopment Analysis System: Version 6.1.4, Amherst, Massachusetts. 
Ali, A. and L. Seiford. (1993) "The Mathematical Programming Approach to Efficiency Analysis," In Fried, H., Lovell, C. and Schmidt S. (eds.) The Measurement of Productive Efficiency: Techniques and Applications, Oxford University Press, New York.

Allen, W. B. and D. Liu. (1995). "Service Quality and Motor Carrier Costs: An Empirical Analysis." The Review of Economics and Statistics 75: 499-510.

American Trucking Association (1993 and 1997) Financial and Operating Statistics, Alexandria, Virginia.

Bowman, C. and K. Daniels. (1995) "The Influence of Functional Expertise on Perceptions of Strategic Priorities." British Journal of Management 6(30): 157-167.

Charnes, A., W. Cooper, and E. Rhodes. (1978) "Measuring the Efficiency of Decision Making Units." European Journal of Operations Research 2: 429-444.

Chow, G. and R. F. Poist. (1984) "The Measurement of Quality and the Transportation Purchase Decision." Logistics and Transportation Review 20 (1): 25-43.

Corsi, T., C. Grimm and J. Feitler. (1992) "The Impact of Deregulation on LTL Motor Carriers: Size, Structure, and Organization." Transportation Journal 32(2): 24-31

Crosby, P. B. (1979) Quality Is Free: The Art of Making Quality Certain. New York: New American Library.

D'Aveni, R.A. (1995) Hypercompetitive Rivalries: Competing in Highly Dynamic Environments New York: Free Press.

Dearborn, D. C. and H. A. Simon. (1958) "Selective Perception: A Note on the Departmental Identification of Executives." Sociometry 21: 140-144.
Dess, G. G. and P.S. Davis. (1984) “Porter's Generic Strategies as Determinants of Strategic Group Membership and Organizational Performance." Academy of Management Journal 27(3): 467-488.

Hambrick, D. C. and P. A. Mason. (1984) "Upper Echelons: The Organization as a Reflection of Its Top Managers." Academy of Management Review 9(2): 193-206.

Hayes, R. H. and W. I. Abernathy. (1980) "Managing Our Way to Economic Decline." Harvard Business Review 58(4): 67-77.

Holcomb, M.C. and K. B. Manrodt. (2000) "The Shippers' Perspective: Transportation and Logistics Trends and Issues." Transportation Journal 40 (1): 15-25.

Lambert, D.M., M.C. Lewis, and J.R. Stock. (1993) "Customer-Focused Strategies for Motor Carriers." Transportation Journal 33: 21-28.

Liu, D. (1993) "Service Quality and Industry Structure: Concentration in the LTL Motor Carrier Industry." Journal of Transport Economics and Policy, 27(3): 305-315.

Logistics Management and Distribution Report (1993 and 1997) Quest for Quality, Radnor, Pennsylvania.

McGinnis, M. A. (1990) "A Comparative Evaluation of Freight Transportation Choice Models." Transportation Journal 29: 36-46.

McGinnis, M. A. (1990) “The Relative Importance of Cost and Service in Freight Transportation Choice: Before and After Deregulation.” Transportation Journal 30(1): 112-119.

Nystrom, P. C. (1991) “Departmental Affiliations and Selective Perceptions of Competitive Strategies." International Journal of Management 11(4): 865-869. 
Official Motor Freight Guide, Inc. (1993 and 1997) Official Motor Carrier Directory, Chicago, Illinois.

Parasuraman, A., V. A. Zeithaml, and L. L. Berry. (1985) "A Conceptual Model of Service Quality and Its Implications for Future Research." Journal of Marketing 49: 39-58.

Taylor, G. D. and T. S. Meinert. (2000). "Improving the Quality of Operations in Truckload Trucking." IIE Transactions 32(6): 551-562.
Walsh, J. P. (1988) "Selectivity and Selective Perception: An Investigation of Managers' Belief Structures and Information Processing." Academy of Management Journal 31(4): 873-896.

Wisner, J. D. and I. A. Lewis. (1996) “Quality Improvement Programs in the Motor Carrier Industry." Transportation Journal 36: 26-34.

\section{AUTHOR BIOGRAPHY}

Patricia M. Poli is assistant professor of accounting at Fairfield University in Fairfield, Connecticut. Her research interests are the strategic financial considerations of multinational firms, the resulting accounting choices they make, and the effects of those choices on the capital markets. Dr. Poli's teaching interests are financial accounting, international accounting, financial statement analysis, and auditing. She has served as an ad hoc reviewer for Journal of International Financial Management and Accounting and The Journal of Business and Economic Studies. Dr. Poli received her Ph.D. in accounting from New York University and a B.S. in accounting from the University of Connecticut.

\section{AUTHOR BIOGRAPHY}

Carl A. Scheraga is associate professor of business strategy and technology management at Fairfield University in Fairfield, Connecticut. His fields of research and teaching include international strategic management, cross-cultural management, the management of high technology and research and development, and transportation and international logistics. Dr. Scheraga has published numerous articles in Management International Review, Transportation Research Series A, Journal of Transportation Management, Transportation Journal, and Journal of the Transportation Research Forum. He also has published chapters in such volumes as Japanese Direct Investment in the United States: Trends, Developments and Issues and International Financial Market Integration. Dr. Scheraga received his Ph.D. in economics from the University of Connecticut, and his M.A. in economics and Sc.B. in mathematics and engineering from Brown University. 